\title{
ISPITNA TJESKOBA KOD UČENIKA UČENIČKIH DOMOVA U REPUBLICI HRVATSKOJ
}

\author{
Siniša Brlas \\ Zavod za javno zdravstvo „Sveti Rok“ Virovitičko-podravske županije, Republika Hrvatska \\ Ana Imrović \\ Dom učenika srednjih škola Antun Gustav Matoš u Zagrebu, Zagreb, Republika Hrvatska \\ Karolina Jukić \\ Srednjoškolski đački dom Osijek, Republika Hrvatska \\ Ivana Martinušić \\ Opća bolnica Virovitica, Republika Hrvatska \\ Tomislav Šokec \\ Zavod za javno zdravstvo „Sveti Rok“ Virovitičko-podravske županije, Republika Hrvatska
}

\begin{abstract}
Sažetak
Rad razmatra temu problema mentalnog zdravlja, odnosno ispitne tjeskobe kod učenika koji borave u učeničkim domovima i njihovu percepciju od strane profesora odgojitelja. Ispitna tjeskoba uobičajena je pojava u situacijama u kojima je potrebno iskazati znanje ili vještine te se prezentirati pred drugima, osobito kada druge osobe procjenjuju uradak. $U$ niskim ili umjerenim razinama ispitna tjeskoba djeluje poticajno i motivira osobu na ulaganje truda u postignuće, dok u visokim razinama djeluje paralizirajuće i često „zakoči“ osobu što dovodi do izostanka odgovarajućeg uspjeha u ispitnoj situaciji. Ako se situacija u kojoj ispitna tjeskoba značajno onemogući postignuće na ispitu višekratno ponovi, dolazi do nemogućnosti ostvarivanja obrazovnih ciljeva što pojedinca dovodi u stanje frustracije pa i stresa, a to nije dobra prognoza za njegovo mentalno zdravlje.

Rezultati provedenog online istraživanja, koje je provedeno u učeničkim domovima diljem Hrvatske, ukazuju da većina učenika doživljava umjerene razine ispitne tjeskobe, ali i da odgajatelji percipiraju veće razine tjeskobe kod učenika nego što oni sami o njima izvještavaju. Također su kvalitativno prikazane najčešće tjelesne i emocionalne promjene kod učenika, misli koje ih prate tijekom ispita te sklonost traženju pomoći od strane odgojitelja.
\end{abstract}

Ključne riječi: ispitna tjeskoba, mentalno zdravlje, odgojitelji, učenici, učenički domovi

\section{UvoD}

Posljednjih se godina, a osobito od kada je u Republici Hrvatskoj na snagu stupila Nacionalna strategija zaštite mentalnog zdravlja za razdoblje od 2011. do 2016. godine, snažno naglašava proaktivan pristup skrbi o mentalnom zdravlju, dakle skrb o mentalnom zdravlju prije nego što se ono naruši jer je uvijek „,bolje spriječiti nego liječiti“.

Nacionalna strategija strateški je okvir za proaktivno djelovanje u različitim resorima, a važnost međusektorske suradnje posebno se ističe u posljednjem od šest područja Nacionalne strategije koje poziva na suradnju, od one interdisciplinarne pa do međusektorske. Slijedom navedenog područja u implementaciji Nacionalne strategije proizlazi i suradnja sustava zdravstva i odgojno-obrazovnog sustava koja je rezultirala izradom vodiča za studente i učenike pod nazivom „Kako prevladati ispitnu tjeskobu“ (Brlas i Martinušić, 2015). Vodič je pokušaj da se 
proaktivna skrb o mentalnom zdravlju usmjeri učeničkoj i studentskoj populaciji, a zapravo se nastoji zaokružiti pristup specifičnoj proaktivnoj skrbi o mentalnom zdravlju mladih tijekom njihova rasta, razvoja i obrazovanja. Svrha je vodiča učenicima i studentima pomoći razvijati toleranciju na stres i frustraciju i poučiti ih navikama i vještinama koje im u tome mogu pomoći.

Ispitna tjeskoba (anksioznost) uobičajena je pojava u situacijama u kojima je potrebno iskazati znanje ili vještine te se prezentirati pred drugima, osobito ako te osobe procjenjuju postignuće. Kada je na niskim ili umjerenim razinama, ispitna tjeskoba djeluje poticajno i motivira osobu na ulaganje truda u postignuće; dakle razvidno je kako „je određena jačina tjeskobe korisna i vodi boljem učinku..." (Hackney i Cormier 2012: 261). Ovakvu tjeskobu stoga zovemo potičuća (poticajna) ili facilitirajuća ispitna tjeskoba. Facilitirajuća anksioznost također je povezana s češćim traženjem podrške, proaktivnošću i suočavanjem usmjerenim na rješavanje problema, za razliku od ometajuće anksioznosti koja je povezana s visokim razinama napetosti i brige te s izbjegavanjem (Raffety, Smith i Ptacek, 1997). Međutim, na visokim razinama ispitna tjeskoba djeluje ometajuće (paralizirajuće) i često „zakoči“ osobu te ona ne uspijeva iskazati svoj puni potencijal, što dovodi do izostanka odgovarajućeg uspjeha u ispitnoj situaciji, pa stoga takvu ispitnu tjeskobu nazivamo ometajućom. Ako se situacija u kojoj ispitna tjeskoba značajno onemogući postignuće na ispitu višekratno ponovi, dolazi do nemogućnosti ostvarivanja obrazovnih ciljeva što pojedinca dovodi u stanje frustracije, stresa pa i mogućeg razvoja socijalnih fobija, a sve to nije dobra prognoza za njegovo mentalno zdravlje.

Mentalno je zdravlje stanje u kojemu osoba ostvaruje svoje sposobnosti, može raditi produktivno i plodno i doprinositi svojoj zajednici, ali se može i nositi sa stresom svakodnevnog života i stoga je potrebno činiti preventivne korake koji će pomoći postizanju ovakvog stanja. Budući da je mentalno zdravlje dio općeg zdravlja i da bez mentalnog zdravlja nema niti općeg zdravlja, jasno je da će činitelji koji mogu narušiti mentalno zdravlje u konačnici često dovesti i do narušavanja općeg zdravlja. Stoga skrbiti o mentalnom zdravlju znači skrbiti o zdravlju općenito, a osobito je važno čuvati mentalno zdravlje u ranoj životnoj dobi. Stoga istraživanjem ispitne tjeskobe dolazimo do podataka važnih za mentalno zdravlje.

Ispitnom se tjeskobom i njezinim utjecajem na različite oblike doživljavanja i ponašanja istraživači bave već dulje, ali je malo istraživanja koja su provedena u specifičnoj populaciji učenika u učeničkim domovima. Također je malo istraživanja koja rezultate povezuju s ciljevima i mjerama najvažnijeg strateškog dokumenta u skrbi o mentalnom zdravlju, a to je Nacionalna strategija zaštite mentalnog zdravlja.

Ovo se istraživanje indirektno bavi i implikacijama nalaza istraživanja na stručne postupke koje mogu poduzimati odgajatelji u učeničkim domovima u specifičnoj odgojno-obrazovnoj situaciji u kojoj s učenicima mogu provoditi kontinuirane i cjelodnevne aktivnosti usmjerene skrbi o njihovom mentalnom zdravlju, a osobito sukladno 2. i 3. mjeri (koje je intencija povećavati sposobnost djece za nošenje s problemima i poboljšati prepoznavanje probleme mentalnog zdravlja kod mladih i adolescenata) u drugom području Nacionalne strategije (unapređenje mentalnog zdravlja u dobno-specifičnim i vulnerabilnim populacijama).

Rezultatima istraživanja željeli smo s jedne strane dati poticaj stručnom radu odgajatelja i stručnih suradnika u učeničkim domovima u dijelu koji se odnosi na proaktivnu skrb o mentalnom zdravlju učenika, a s druge strane istovremeno povezujući dobivene nalaze s prednostima korištenja raspoloživih alata za reduciranje (pred)ispitne tjeskobe, na primjer spomenutog vodiča "Kako prevladati ispitnu tjeskobu“.

\section{Metoda}

Ovo je istraživanje provedeno u učeničkim domovima u Republici Hrvatskoj u kojima učenici osim što imaju osigurane uvjete za boravak i prehranu sudjeluju u brojnim mentorskim, 
S. Brlas, A. Imrović, K. Jukić, I. Martinušić, T. Šokec ISPITNA TJESKOBA KOD UČENIKA UČENIČKIH DOMOVA U..

izbornim i posebnim programima. Ti su programi osmišljeni kako bi podržali cjelokupni razvoj učenika, a između ostaloga pružaju i pomoć u učenju. Za razliku od učenika koji pohađaju srednje škole iz svojih roditeljskih domova, učenici koji su smješteni u učeničkim domovima imaju jednu značajnu prednost - mogu se u svakom dijelu dana osloniti na pomoć stručnjaka. S njima su u učeničkom domu tijekom dana njihovi odgajatelji (različitih profila stručnosti), stručni suradnici (pedagozi, psiholozi, socijalni pedagozi) i medicinske sestre. Svi oni mogu pružiti određenu vrstu pomoći učenicima u različitim situacijama, pa i kad se suočavaju s ispitnom tjeskobom.

Ideja je ovoga istraživanja da se iskoristi upravo ovaj potencijal stručnog djelovanja u smjeru dodatnih aktivnosti vezanih uz skrb o mentalnom zdravlju učenika. Istraživanjem se željelo osvijestiti postojanje ispitne tjeskobe i naglasiti povezanost ispitne tjeskobe s obrazovnim postignućem i mentalnim zdravljem mladih, a nakon toga potaknuti stručnjake na aktivnosti usmjerene suzbijanju potencijalnih rizika. Stoga je osmišljeno on-line istraživanje koje je provedeno među učenicima i odgajateljima učeničkih domova i kojim se željelo postići ovaj glavni cilj, pa je stoga istraživanje obuhvatilo dolje navedene probleme.

U prvom su koraku pripreme ovoga istraživanja odgajatelji i stručni suradnici u učeničkim domovima kroz radionički pristup na svom stručnom vijeću organiziranom na državnoj razini kreirali upitnike o ispitnoj tjeskobi. Jedan je upitnik namijenjen učenicima, a drugi njihovim odgajateljima i stručnim suradnicima. Oba su upitnika u prilogu ovome članku. Potom su na temelju toga izrađeni on-line oblici upitnika koji su putem internetske veze (linka) učinjeni dostupni svim učeničkim domovima u Republici Hrvatskoj. U učeničkim su domovima odgajatelji i stručni suradnici potom motivirali učenike na dobrovoljno sudjelovanje $u$ istraživanju, a u istom su i sami sudjelovali, svatko od njih ispunjavajući odgovarajući oblik upitnika. Učenicima su prethodno objašnjeni ciljevi istraživanja i ukazalo im se na mogućnosti primjene nalaza istraživanja kako bi ih se zainteresiralo i motiviralo na sudjelovanje. Svatko je sam (individualno), diskretno i anonimno ispunjavao on-line oblik upitnika.

\section{Problemi istraživanja}

Ovim istraživanjem željeli smo ispitati koliko je ispitna tjeskoba prisutna u populaciji učenika koji su smješteni u učeničkim domovima, koliko je prepoznata od strane odgajatelja i stručnih suradnika koji skrbe o učenicima, što dovodi do ispitne tjeskobe, koje promjene učenici prepoznaju kad su izloženi ispitnoj tjeskobi te koji su načini na koji se učenici i odgajatelji nose s ovim problemom. Istraživanje je zato obuhvatilo:

1. subjektivnu procjenu (samoprocjenu) intenziteta ispitne tjeskobe kojoj su izloženi učenici učeničkih domova,

2. utvrđivanje razlikuje li se (samo)procjena intenziteta ispitne tjeskobe učenika od procjena intenziteta izloženosti učenika ispitnoj tjeskobi koju daju njihovi odgajatelji,

3. psihosomatske promjene, emocije i misli koji prate ispitnu tjeskobu,

4. uzroke ispitne tjeskobe $\mathrm{i}$

5. načine suočavanja s ispitnom tjeskobom.

\section{Instrumenti i postupak}

Za procjenu intenziteta ispitne tjeskobe korišteni su upitnici o ispitnoj tjeskobi. Razvijena su dva upitnika: jedan je upitnik bio namijenjen učenicima, a drugi njihovim odgajateljima i stručnim suradnicima. Upitnici su izrađeni na stručnom skupu stručnih suradnika i odgajatelja u učeničkim domovima i nisu provjeravane njihove metrijske karakteristike, ali su ipak ocijenjeni dovoljno informativnima s obzirom na probleme istraživanja. 
$U$ istraživanju su korištene on-line verzije za oba upitnika. Ovoj su verziji upitnika mogli pristupiti svi učenici, odgajatelji i stručni suradnici iz svih učeničkih domova u Republici Hrvatskoj. Istraživanje je bilo anonimno i dobrovoljno. Učenike su na sudjelovanje u istraživanju animirali i motivirali njihovi odgajatelji i stručni suradnici, a provedeno je u svim učeničkim domovima u Republici Hrvatskom u studenom i prosincu 2017. godine. Upitnike je ispunilo ukupno 509 učenika (346 djevojaka i 163 dječaka) u dobi između 14 i 18 godina te 86 odgajatelja (72 odgajateljice i 14 odgajatelja) različite životne dobi. S obzirom na anonimnost i postavljene probleme nije se tražio podatak o dobi odgajatelja i stručnih suradnika pa stoga nije niti poznata dobna struktura odgajatelja i stručnih suradnika koji su odgovarali na pitanja, niti je to bilo relevantno za postavljene probleme istraživanja.

\section{REZULTATI I RASPRAVA}

S obzirom da se istraživanjem željelo osvijestiti postojanje ispitne tjeskobe i naglasiti povezanost ispitne tjeskobe s obrazovnim postignućem i mentalnim zdravljem mladih, te nakon toga potaknuti stručnjake na aktivnosti usmjerene suzbijanju potencijalnih rizika slijedom smjernica Nacionalne strategije, smatramo kako je deskriptivna statistička obrada dostatna za komentiranje nalaza istraživanja i za postizanje glavnoga cilja.

Istraživanje je pokazalo, što se vidi u grafičkom prikazu broj 1, kako ispitani učenice i učenici u ispitnim situacijama doživljavaju ispitnu tjeskobu i kako se procjena intenziteta ispitne tjeskobe raspoređuje gotovo u pravilnoj distribuciji Gaussova tipa. Niz ranijih istraživanja sugerira kako se razina ispitne tjeskobe povećava s dobi adolescenata dostižući najvišu razinu na kojoj se stabilizira oko 18 godine života (Čibarić 2015: 27), što ovdje nije istraživano. Najveći broj ispitanih (njih oko trećina) procjenjuju da su tijekom ispitne situacije izloženi srednjem stupnju ispitne tjeskobe, odnosno niti su osobito tjeskobni niti su sasvim opušteni, zatim gotovo trećina njih iskazuje izraženiji stupanj ispitne tjeskobe, dok približno trećina procjenjuje da su $\mathrm{u}$ ispitnim situacijama uglavnom ili sasvim opušteni. Dobiveni podaci su u skladu i s ranije provedenim istraživanjima, gdje oko $30 \%$ učenika ima izraženiju tjeskobu koja ih ometa u svakodnevnom radu (Shaked 1996., prema Lufi, Okasha i Cohen, 2004). S obzirom na ranije rezultate nekih istraživanja koji su testirali statističku značajnost razlike u intenzitetu ispitne tjeskobe s obzirom na spol, a koji sugeriraju kako ispitanici oba spola pokazuju podjednaku razinu ukupne ispitne tjeskobe (Čibarić 2015: 27), smatrali smo da nije bilo potrebno testirati statističku značajnost ove razlike.

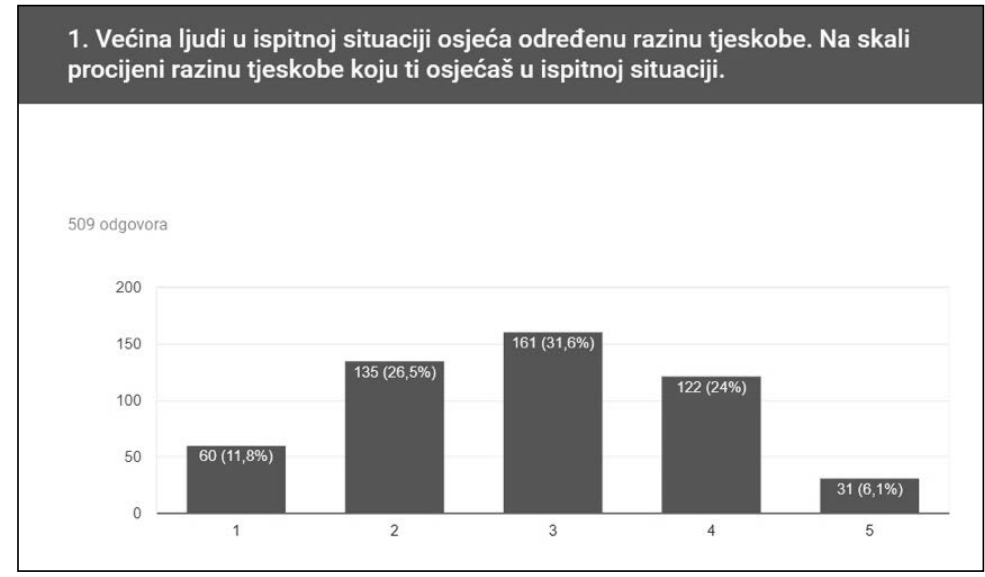

Slika 1. Razina tjeskobe koju doživljavaju učenici (apsolutni broj i u postocima) 
S. Brlas, A. Imrović, K. Jukić, I. Martinušić, T. Šokec ISPITNA TJESKOBA KOD UČENIKA UČENIČKIH DOMOVA U..

U slici 1. prikazani su rezultati procjene razine ispitne tjeskobe kod učenika iz perspektive njihovih odgajatelja. Ovdje se vizualnom inspekcijom može uočiti kako odgajatelji i stručni suradnici razinu ispitne tjeskobe kod učenika procjenjuju višom nego što ju procjenjuju sami učenici (statistička značajnost ove razlike u procjenama nije testirana). Odgajatelji i stručni suradnici očito imaju širi uvid u predispitnu i ispitnu situaciju promatrajući sve učenike, dok se svaki pojedini učenik očito oslanja isključivo na vlastiti introspektivni uvid ne uzimajući u obzir samoprocjene ostalih učenika, pa se ovdje može tražiti uzrok ove razlike u procjenama.

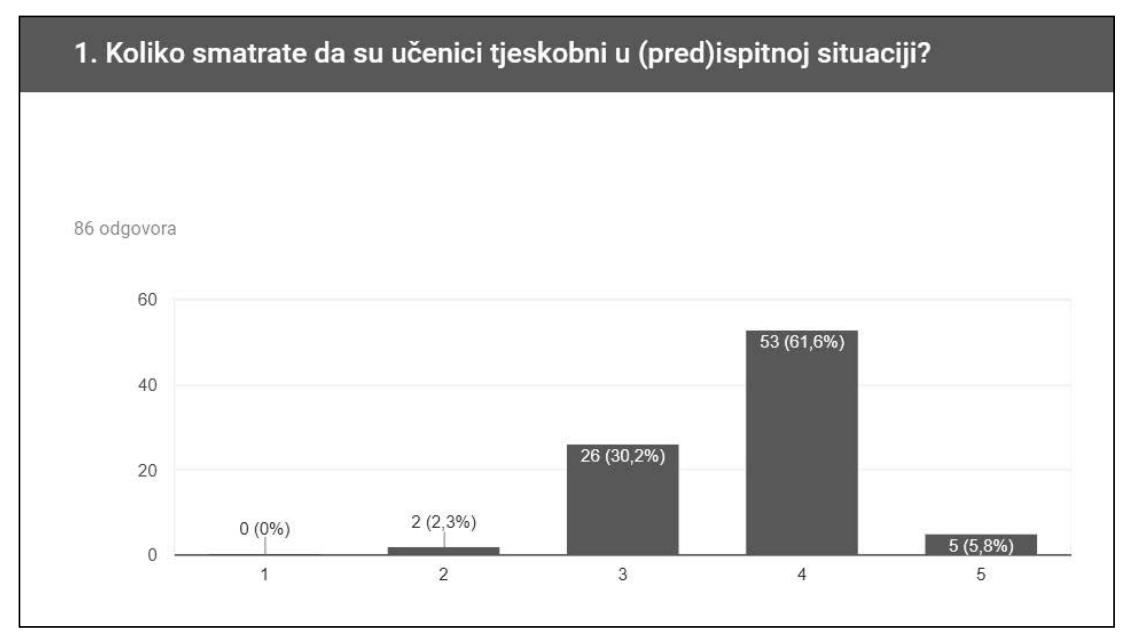

Slika 2. Razina tjeskobe koju kod učenika percipiraju odgajatelji (apsolutni broj i u postocima)

Uz ispitnu tjeskobu dolaze i psihosomatske promjene, a iz tablice 1 vidljivo je da su kod ispitanih najizraženije lupanje srca (uz ubrzano disanje ili hiperventiliranje kod dijela ispitanih, uvjetovanih vjerojatno dodatnom potrebom za kisikom zbog zahtjeva ispitne situacije), zatim znojenje i želučane tegobe (uz osjećaj mučnine kod dijela ispitanika). U manjem postotku ispitanici osjećaju i drhtavice, glavobolje ili neke druge promjene osim navedenih. Značajan postotak ispitanih (oko 22\%) izjavljuje da ne osjeća psihosomatske senzacije vezane uz ispitnu situaciju, a za pretpostaviti je da se radi o onima koji su izvijestili da su u ispitnim situacijama opušteniji odnosno da nisu osobito tjeskobni, dakle onima koji su svojim odgovorima o izloženosti ispitnoj tjeskobi locirani u lijevom dijelu Gaussove raspodjele (u grafičkom prikazu broj 1).

Niti ovdje nije testirana statistička značajnost razlike po spolu jer su nalazi ranijih istraživanja prilično konzistentni u spoznaji da su fiziološke manifestacije koje prate ispitnu tjeskobu značajno prisutnije kod ženskog spola (Čibarić 2015: 27). U literaturi se još uvijek vode rasprave o tome je li to stoga što su ženske osobe zaista više tjeskobne ili su možda samo spremnije izvijestiti o svojoj tjeskobi. Ovi nalazi zato mogu biti dobra osnova za raspravu s učenicima o usvajanju spolnih uloga u životu. 
Tablica 1. Prikaz tjelesnih promjena koje učenici najčešće doživljavaju u ispitnoj situaciji

\begin{tabular}{|c|c|c|c|c|c|c|}
\hline \multirow{2}{*}{$\begin{array}{l}\text { Spol ispitanika } \\
\text { Odgovori }\end{array}$} & \multicolumn{2}{|c|}{ Ženski } & \multicolumn{2}{|c|}{ Muški } & \multicolumn{2}{|c|}{ Ukupno } \\
\hline & $\mathrm{N}$ & $\%$ & $\mathrm{~N}$ & $\%$ & $\mathrm{~N}$ & $\%$ \\
\hline a) Bolovi u trbuhu & 49 & $14,16 \%$ & 9 & $5,52 \%$ & 58 & $11,39 \%$ \\
\hline b) Znojenje & 48 & $13,87 \%$ & 25 & $15,34 \%$ & 73 & $14,34 \%$ \\
\hline c) Lupanje srca & 114 & $32,95 \%$ & 32 & $19,63 \%$ & 146 & $28,68 \%$ \\
\hline d) Mučnina & 19 & $5,49 \%$ & 4 & $2,45 \%$ & 23 & $4,52 \%$ \\
\hline e) Ubrzano disanje & 16 & $4,62 \%$ & 8 & $4,91 \%$ & 24 & $4,72 \%$ \\
\hline f) Glavobolje & 15 & $4,34 \%$ & 8 & $4,91 \%$ & 23 & $4,52 \%$ \\
\hline g) Drhtavice & 35 & $10,12 \%$ & 6 & $3,68 \%$ & 41 & $8,06 \%$ \\
\hline *h) Nešto drugo & 4 & $1,16 \%$ & 5 & $3,07 \%$ & 9 & $1,77 \%$ \\
\hline i) Ne uočavam tjelesne promjene & 46 & $13,29 \%$ & 66 & $40,49 \%$ & 112 & $22,00 \%$ \\
\hline UKUPNO ODGOVORA & 346 & $100,00 \%$ & 163 & $100,00 \%$ & 509 & $100,00 \%$ \\
\hline
\end{tabular}

*h) Nešto drugo(4Ž+5M=9): Hladno mi je-1Ž, Nervoza-1Ž, Ništa-1Ž+1M, Sve navedeno-1Ž+1M, Grizem nokte-1M, Potreba za velikom nuždom-1M, Skoro sve-1M

U tablici 2 prikazani su nalazi o tome koje emocije ili čuvstva učenici doživljavaju u ispitnim situacijama. Trećina od ukupnog broja ispitanih osjeća nesigurnost, vjerojatno uvjetovanu nedovoljnom pripremljenošću za ispit o kojoj izvještava više od trećine ispitanih (tablica 4). Slijedi nervoza (zbog neizvjesnog ishoda), zatim strah (uglavnom od neuspjeha), pa čak i panika kod dijela onih kojima je vjerojatno uspjeh na ispitu osobito važan jer mogući neuspjeh može imati osobito nepovoljne posljedice za njihovo daljnje školovanje. Također, određeni broj ispitanih izjavljuje da su ravnodušni ili ne doživljavaju nikakve osobite emocije u ispitnim situacijama, a to su vjerojatno oni koji su u ispitnim situacijama opušteni. Značajno je navesti kako je moguće da su određene emocije, osobito strah i panika, tek indirektno povezane s ispitnom tjeskobom, i to na način da se pristupnici ispitu uplaše doživljaja vlastitih fizioloških promjena koje su reakcija na ispitnu situaciju, tako da emocije mogu biti i uzrokom fizioloških promjena, ali mogu biti i odgovor na psihosomatiku vezanu uz ispitnu situaciju.

„Anksioznost vezana uz postignuće pojavljuje se u dva oblika: kao kognitivna zabrinutost i kao psihološka uzrujanost („hiperemocionalnost“).“ (Reeve 2010: 185). Dosadašnje spoznaje upućuju na to da povišena emocionalna uzbuđenost koja prati ispitnu situaciju ne umanjuje izvedbu na samom ispitu, za razliku od kognitivne zabrinutosti. Za odgajatelje i učitelje (kao i ostale psihoedukatore) koristan bi bio savjet da se u radu s učenicima orijentiraju poučavanju strategija učenja i pripremanja za ispit koje će biti usmjerene što uspješnijoj izvedbi (rješavanju zadataka), umjesto onih usmjerenih izbjegavanju neuspjeha. „Tjeskoba koja se temelji na zabrinutosti i koja uistinu negativno utječe na (...) izvedbu oslabjet će u onoj mjeri u kojoj su ciljevi izbjegavanja izvedbe uspješno pretvoreni u ciljeve orijentirane na pristupanje." (Reeve 2010: 185). Temeljni je savjet da se djeluje u smjeru promjene načina na koji učenici razmišljaju u (pred)ispitnim situacijama, što ponovno aktualizira doprinos psihoedukacije učenika u procesu pripremanja za ispite.

Pomalo iznenađuje nalaz prema kojemu više od četvrtine ispitanih locira uzroke neugodnih emocija u samim ispitivačima (profesorima/nastavnicima), što upućuje na vrlo veliki prostor za djelovanjem u smislu dodatne psihoedukacije nastavnika. Važnu ulogu nastavnika-ispitivača, 
S. Brlas, A. Imrović, K. Jukić, I. Martinušić, T. Šokec ISPITNA TJESKOBA KOD UČENIKA UČENIČKIH DOMOVA U...

ne uvijek pozitivnu, u ispitnim situacijama potkrjepljuju i nalazi ovoga istraživanja prema kojima je većini učenika lakši pisani ispit, zatim nalaz da se gotovo dvije trećine učenika nije sklono za pomoć obratiti svojim nastavnicima kao i to da misle kako njihovi nastavnici uopće ne prepoznaju ispitnu tjeskobu kod njih (učenika). Također, gotovo svaki drugi ispitanik ima iskustvo da razgovor s nastavnikom/odgajateljem o ispitnoj tjeskobi nikada ili gotovo nikada ne umanjuje njihovu tjeskobu. Ovo pokazuje kako nastavnici i/ili odgajatelji ne koriste u potpunosti svoje edukacijske kapacitete kako bi pomogli učenicima u suočavanju s tjeskobom vezanom za ispit. Ipak, navedeni rezultati mogu se objasniti tezom koju postavlja Sorić (2014) i koji navodi kako doživljavanje stresa u školskim situacijama predstavlja kružni proces. Sukobi u razredu, sukobi s nastavnicima, prevelika očekivanja roditelja, poteškoće u učenju, pisanje testova i ocjenjivanje dovode do intenzivnog doživljaja stresa kod učenika. Pod utjecajem takvog stresa osoba neće biti u mogućnosti uspješno svladati gradivo, što za posljedicu ima školski neuspjeh i ponovno pojačan doživljaj stresa. Postoje brojna istraživanja koja govore o povezanosti doživljavanja stresa kod učenika i studenata i niza negativnih posljedica vezanih uz tjelesno i psihičko zdravlje.

Tablica 2. Prikaz emocija koje učenici najčešće doživljavaju u ispitnoj situaciji

\begin{tabular}{|l|r|r|r|r|r|r|}
\hline \multicolumn{2}{|c|}{ Što od navedenog najviše osjećaš u ispitnoj situaciji. (odaberi samo jedno, ono najizraženije)? } \\
\hline Spol ispitanika & \multicolumn{2}{|c|}{ Ženski } & \multicolumn{2}{c|}{ Muški } & \multicolumn{2}{c|}{ Ukupno } \\
\hline Odgovori & \multicolumn{1}{c|}{$\mathrm{N}$} & \multicolumn{1}{c|}{$\%$} & $\mathrm{~N}$ & \multicolumn{1}{c|}{$\%$} & $\mathrm{~N}$ & \multicolumn{1}{c|}{$\%$} \\
\hline a) Strah & 60 & $17,34 \%$ & 17 & $10,43 \%$ & 77 & $15,13 \%$ \\
\hline b) Sram & 2 & $0,58 \%$ & 0 & $0,00 \%$ & 2 & $0,39 \%$ \\
\hline c) Nesigurnost & 112 & $32,37 \%$ & 59 & $36,20 \%$ & 171 & $33,60 \%$ \\
\hline d) Paniku & 46 & $13,29 \%$ & 10 & $6,13 \%$ & 56 & $11,00 \%$ \\
\hline e) Ljutnju & 3 & $0,87 \%$ & 2 & $1,23 \%$ & 5 & $0,98 \%$ \\
\hline f) Nervozu & 86 & $24,86 \%$ & 26 & $15,95 \%$ & 112 & $22,00 \%$ \\
\hline g) Ravnodušnost & 15 & $4,34 \%$ & 13 & $7,98 \%$ & 28 & $5,50 \%$ \\
\hline *h) Nešto drugo & 1 & $0,29 \%$ & 3 & $1,84 \%$ & 4 & $0,79 \%$ \\
\hline i) Ništa & 21 & $6,07 \%$ & 33 & $20,25 \%$ & 54 & $10,61 \%$ \\
\hline UKUPNO ODGOVORA & $\mathbf{3 4 6}$ & $\mathbf{1 0 0 , 0 0 \%}$ & $\mathbf{1 6 3}$ & $\mathbf{1 0 0 , 0 0 \%}$ & $\mathbf{5 0 9}$ & $\mathbf{1 0 0 , 0 0 \%}$ \\
\hline
\end{tabular}

*h) Nešto drugo $(1 Z ̌+3 M=4)$ : Većinu od navedenog-1Ž, (Nesigurnost, paniku, nervozu)-1M, Smijeh-1M, Sve navedeno-1M

Nesigurnost, nervozu i paniku u ispitnim situacijama prate i misli adekvatne navedenim emocionalnim stanjima, a u tablici 3 uočava se kako su rezultati ovoga istraživanja pokazali da čak tri četvrtine ispitanih razmišlja o mogućim nepovoljnim ishodima negativnog postignuća na ispitu (brinu hoće li ispasti glupi, što će reći drugi i sl.). lako usmjerenost na što uspješniju izvedbu u ispitnoj situaciji kod velikog broja učenika uvjetuje pojavljivanje tjeskobe koja potencijalno ometa postizanje uspješnog školskog postignuća (Šimić i Sorić, 2011), ipak je za uspjeh na ispitu pogubnija usmjerenost na očekivanje neuspjeha, kako navodi Reeve 2010.

Tek nešto manje od polovine ukupnog broja, dakle gotovo svaki drugi ispitanik, misli kako mu se gradivo pomiješalo. Ove su misli vjerojatno posljedica nedovoljne naučenosti gradiva ili učenja u posljednji čas (tzv. kampanjskog učenja). Ovi rezultati u skladu su s modelom interferencije koji 1980. godine objašnjava Tyron, prema kojem utjecaj ispitne tjeskobe na školska dostignuća postoji na način da visoko tjeskobni učenici dobro usvoje potrebne infor- 
macije, ali imaju poteškoća u dosjećanju zato jer irelevantne misli skreću pažnju s onih misli koje su relevantne za zadatak te na taj način sprječavaju dozivanje informacija koje su nužne za davanje točnog odgovora (Živčić-Bećirević, 2005).

Tablica 3. Prikaz misli koje se najčešće javljaju u ispitnim situacijama

\begin{tabular}{|l|r|r|r|r|r|r|}
\hline \multicolumn{2}{|c|}{ Koje ti se misli najčešće javljaju za vrijeme ispitivanja (odaberi samo jedno, ono najčešće) } \\
\hline Spol ispitanika & \multicolumn{2}{|c|}{ Ženski } & \multicolumn{2}{c|}{ Muški } & \multicolumn{2}{c|}{ Ukupno } \\
\hline Odgovori & \multicolumn{1}{|c|}{$\mathrm{N}$} & \multicolumn{1}{c|}{$\%$} & $\mathrm{~N}$ & $\mathrm{~N}$ & \multicolumn{1}{c|}{$\%$} \\
\hline $\begin{array}{l}\text { a) Baš sam zadovoljan/na kako sam } \\
\text { naučio/la }\end{array}$ & 15 & $4,34 \%$ & 16 & $9,82 \%$ & 31 & $6,09 \%$ \\
\hline b) Dobit ću dobru ocjenu & 39 & $11,27 \%$ & 34 & $20,86 \%$ & 73 & $14,34 \%$ \\
\hline c) Pitanja su baš lagana & 15 & $4,34 \%$ & 17 & $10,43 \%$ & 32 & $6,29 \%$ \\
\hline d) Ispast ću glup/a & 22 & $6,36 \%$ & 2 & $1,23 \%$ & 24 & $4,72 \%$ \\
\hline e) Ništa ne znam & 41 & $11,85 \%$ & 9 & $5,52 \%$ & 50 & $9,82 \%$ \\
\hline f) Sve mi se pomiješalo & 161 & $46,53 \%$ & 49 & $30,06 \%$ & 210 & $41,26 \%$ \\
\hline g) Dobit ću jedan & 33 & $9,54 \%$ & 15 & $9,20 \%$ & 48 & $9,43 \%$ \\
\hline h) Što će mi reći roditelji & 14 & $4,05 \%$ & 14 & $8,59 \%$ & 28 & $5,50 \%$ \\
\hline *) Nešto drugo & 6 & $1,73 \%$ & 7 & $4,29 \%$ & 13 & $2,55 \%$ \\
\hline UKUPNO ODGOvORA & $\mathbf{3 4 6}$ & $\mathbf{1 0 0 , 0 0 \%}$ & $\mathbf{1 6 3}$ & $\mathbf{1 0 0 , 0 0 \%}$ & $\mathbf{5 0 9}$ & $\mathbf{1 0 0 , 0 0 \%}$ \\
\hline
\end{tabular}

*i) Nešto drugo $(6 \check{Z}+7 \mathrm{M}=13)$ : Sve od navedenog-2Ž, Od koga prepisati?-1Ž, Rasturiti ću-1Ž, Samo da ne pita nešto teško-1Ž, Sve će biti dobro-1Ž, Nikakve-2M, Što sada?-1M, Svejedno mi-1M, Boli me briga!-1M, Jesam li dobro odgovorio?-1M, Dobit ću dobru ocjenu *dobije dva-1M

Neugodne emocije dominiraju doživljajnim aspektom ispitne situacije, kako je to prethodno prikazano u tablici 3, one su ustvari uzrokom ispitne tjeskobe, a u tablici 4 mogu se locirati najčešći uzroci ovih emocionalnih stanja kod ispitanika. Samoopažanjem (introspekcijom) ispitani učenici daju naslutiti kako je nedovoljna pripremljenost za ispit najčešći uzrok neugodnih emocija intenzitet kojih može biti takav da dođe do tzv. emocionalnog preplavljivanja u kojemu emocije ometaju kognitivno funkcioniranje, a time naravno i postignuće na ispitu. Ovo saznanje može biti korisno odgajateljima koji sudjeluju u pripremanju učenika za ispite kako bi više truda i/ili vremena uložili u aktivnost pripreme za ispit. 
S. Brlas, A. Imrović, K. Jukić, I. Martinušić, T. Šokec ISPITNA TJESKOBA KOD UČENIKA UČENIČKIH DOMOVA U...

Tablica 4. Prikaz najčešćih uzroka straha i neugode za vrijeme ispitivanja kod učenika

\begin{tabular}{|l|r|r|r|r|r|r|}
\hline Najčešći uzrok mog straha i neugode od ispitivanja je(odaberi samo jedan, onaj najčešći uzrok): \\
\hline Spol ispitanika & \multicolumn{2}{|c|}{ Ženski } & \multicolumn{2}{|c|}{ Muški } & \multicolumn{2}{c|}{ Ukupno } \\
\hline Odgovori & $\mathrm{N}$ & \multicolumn{1}{c|}{$\%$} & $\mathrm{~N}$ & \multicolumn{1}{c|}{$\%$} & $\mathrm{~N}$ & \multicolumn{1}{c|}{$\%$} \\
\hline a) Nedovoljna pripremljenost & 126 & $36,42 \%$ & 64 & $39,26 \%$ & 190 & $37,33 \%$ \\
\hline b) Profesor & 98 & $28,32 \%$ & 36 & $22,09 \%$ & 134 & $26,33 \%$ \\
\hline c) Nastavno gradivo & 59 & $17,05 \%$ & 29 & $17,79 \%$ & 88 & $17,29 \%$ \\
\hline d) Neispavanost & 52 & $15,03 \%$ & 21 & $12,88 \%$ & 73 & $14,34 \%$ \\
\hline e) Nešto drugo & 11 & $3,18 \%$ & 13 & $7,98 \%$ & 24 & $4,72 \%$ \\
\hline UKUPNO ODGOVORA & $\mathbf{3 4 6}$ & $\mathbf{1 0 0 , 0 0 \%}$ & $\mathbf{1 6 3}$ & $\mathbf{1 0 0 , 0 0 \%}$ & $\mathbf{5 0 9}$ & $\mathbf{1 0 0 , 0 0 \%}$ \\
\hline
\end{tabular}

*e) Nešto drugo $(11 Z ̌+13 M=24)$ : Nesigurnost-1Ž, Razred-1Ž, Sve-1Ž+1M, Trema-1Ž, Strah od jedinice-1Ž, Reakcija roditelja-1Ž+1M, Strah da ću ispasti glupa-2Ž, Nema straha-1Ž+8M

U tablici 4. naslućuje se da se učenici ne nose jednako sa svim ispitnim situacijama, odnosno preferiraju pismeni oblik ispita jer kod takvog ispitivanja vjerojatno imaju i manju ispitnu tjeskobu. Razlozi za to su u činjenici da je u pismenom obliku odgovaranja moguću pogrešku jednostavnije korigirati i to se može činiti više puta tijekom ispita, dok kod usmenog ispitivanja raste vjerojatnost da će pogrešan odgovor biti kod ispitivača karakteriziran kao konačni, što je za ispitanog nepovoljan ishod. Time raste socijalni pritisak na onoga koji odgovara, a time i tjeskoba koja proizlazi iz njihovog međusobnog socijalnog odnosa.

Tablica 5. Preferirani način odgovaranja kod učenika

\begin{tabular}{|l|r|r|r|r|r|r|}
\hline Kako ti je lakše odgovarati? & \multicolumn{2}{|c|}{ Ženski } & \multicolumn{2}{c|}{ Muški } & \multicolumn{2}{c|}{ Ukupno } \\
\hline Spol ispitanika & \multicolumn{1}{|c|}{$\mathrm{N}$} & \multicolumn{1}{c|}{$\%$} & $\mathrm{~N}$ & $\%$ & $\mathrm{~N}$ & $\%$ \\
\hline Odgovori & 185 & $53,47 \%$ & 50 & $30,67 \%$ & 235 & $46,17 \%$ \\
\hline a) Pismeno & 79 & $22,83 \%$ & 61 & $37,42 \%$ & 140 & $27,50 \%$ \\
\hline b) Usmeno & 82 & $23,70 \%$ & 52 & $31,90 \%$ & 134 & $26,33 \%$ \\
\hline c) Svejedno mi je & $\mathbf{3 4 6}$ & $\mathbf{1 0 0 , 0 0 \%}$ & $\mathbf{1 6 3}$ & $\mathbf{1 0 0 , 0 0 \%}$ & $\mathbf{5 0 9}$ & $\mathbf{1 0 0 , 0 0 \%}$ \\
\hline UKUPNO ODGOVORA & & & & &
\end{tabular}

Očekivalo bi se da su odgajatelji, osobito oni s iskustvom, senzibilizirani za prepoznavanje znakova ispitne tjeskobe kod učenika te za djelovanje, ali nalazi prikazani u tablici 6 demantiraju ovo očekivanje. Naime, kako je vidljivo, učenici izvještavaju da u velikom postotku, čak u više od trećine slučajeva, kada odgajatelji zamijete ispitnu tjeskobu kod učenika s njima o tome ne razgovaraju. Zbog toga se vjerojatno veliki broj učenika (tablica 7) niti ne obrati odgajateljima i/ili nastavnicima za pomoć, a samo svaki drugi učenik smatra (tablica 8) razgovor s odgajateljem i/ili nastavnikom korisnim za ublažavanje ispitne tjeskobe.

Kako je za prorađivanje ove teme potrebno izvjesno znanje o mehanizmima nastanka i nošenja s tjeskobom, za zaključiti je da nemaju možda svi odgajatelji dovoljno kompetencija nositi se s ovim teškoćama kod učenika. Stoga je važno (psiho)educirati odgajatelje (ali i ostale nastavnike) o tome kako pomoći učenicima da razviju vještine suočavanja s tjeskobom i stresom. Spomenuti vodič „Kako prevladati ispitnu tjeskobu“ može ponuditi pomoć na tome putu, osobito u uvodnom dijelu publikacije. 
Tablica 6. Percepcija učenika o uključenosti profesora/odgajatelja u ublažavanje tjeskobe kada je zamijećena

\begin{tabular}{|l|r|r|r|r|r|r|}
\hline \multicolumn{2}{|l|}{ Kada profesori/odgajatelji zamijete da osjećam ispitnu tjeskobu razgovaraju sa mnom o tome. } \\
\hline Spol ispitanika & \multicolumn{2}{|c|}{ Ženski } & \multicolumn{2}{c|}{ Muški } & \multicolumn{2}{c|}{ Ukupno } \\
\hline Odgovori & \multicolumn{1}{c|}{$\mathrm{N}$} & \multicolumn{1}{c|}{$\%$} & $\mathrm{~N}$ & \multicolumn{1}{c|}{$\%$} & $\mathrm{~N}$ & \multicolumn{1}{c|}{$\%$} \\
\hline Nikad & 140 & $40,46 \%$ & 48 & $29,45 \%$ & 188 & $36,94 \%$ \\
\hline Rijetko & 72 & $20,81 \%$ & 29 & $17,79 \%$ & 101 & $19,84 \%$ \\
\hline Ponekad & 71 & $20,52 \%$ & 59 & $36,20 \%$ & 130 & $25,54 \%$ \\
\hline Često & 33 & $9,54 \%$ & 15 & $9,20 \%$ & 48 & $9,43 \%$ \\
\hline Uvijek & 30 & $8,67 \%$ & 12 & $7,36 \%$ & 42 & $8,25 \%$ \\
\hline UKUPNO ODGOVORA & $\mathbf{3 4 6}$ & $\mathbf{1 0 0 , 0 0 \%}$ & $\mathbf{1 6 3}$ & $\mathbf{1 0 0 , 0 0 \%}$ & $\mathbf{5 0 9}$ & $\mathbf{1 0 0 , 0 0 \%}$ \\
\hline
\end{tabular}

Tablica 7. Prikaz sklonosti traženju pomoći u vrijeme pripreme ispita

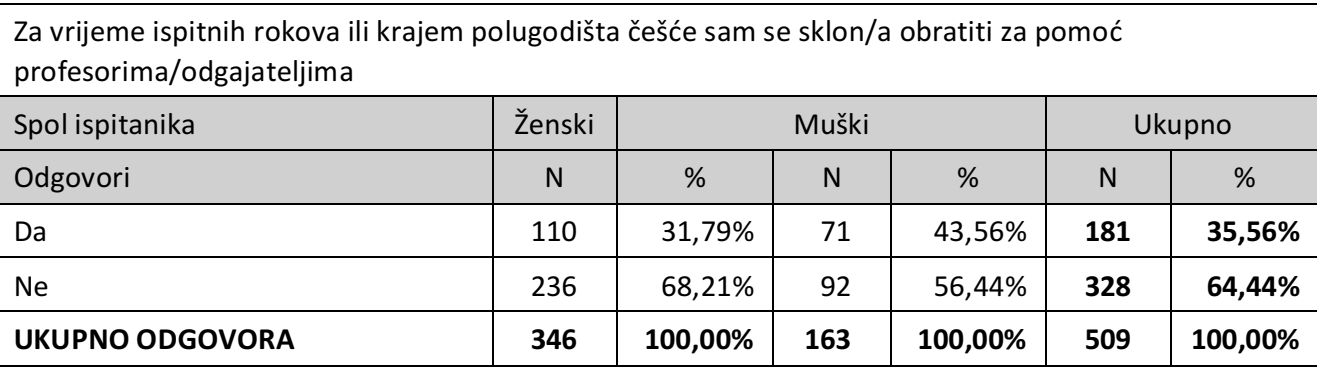

Tablica 8. Percepcija korisnosti razgovora s odgajateljem u svrhu ublažavanja tjeskobe

\begin{tabular}{|l|r|r|r|r|c|c|}
\hline \multicolumn{7}{|c|}{ Razgovor s odgajateljem/profesorom o problemu s ispitnom tjeskobom umanjuje moj problem. } \\
\hline Spol ispitanika & \multicolumn{2}{|c|}{ Ženski } & \multicolumn{2}{c|}{ Muški } & \multicolumn{2}{c|}{ Ukupno } \\
\hline Odgovori & \multicolumn{1}{|c|}{$\mathrm{N}$} & \multicolumn{1}{c|}{$\%$} & $\mathrm{~N}$ & $\%$ & $\mathrm{~N}$ & $\%$ \\
\hline Nikad & 90 & $26,01 \%$ & 42 & $25,77 \%$ & 132 & $25,93 \%$ \\
\hline Rijetko & 87 & $25,14 \%$ & 30 & $18,40 \%$ & 117 & $22,99 \%$ \\
\hline Ponekad & 85 & $24,57 \%$ & 56 & $34,36 \%$ & 141 & $27,70 \%$ \\
\hline Često & 55 & $15,90 \%$ & 18 & $11,04 \%$ & 73 & $14,34 \%$ \\
\hline Uvijek & 29 & $8,38 \%$ & 17 & $10,43 \%$ & 46 & $9,04 \%$ \\
\hline UKUPNO ODGOVORA & $\mathbf{3 4 6}$ & $\mathbf{1 0 0 , 0 0 \%}$ & $\mathbf{1 6 3}$ & $\mathbf{1 0 0 , 0 0 \%}$ & $\mathbf{5 0 9}$ & $\mathbf{1 0 0 , 0 0 \%}$ \\
\hline
\end{tabular}

\section{ZAKUUČAK}

Rezultati provedenog istraživanja pokazali su da su učenici tijekom ispita uglavnom izloženi ispitnoj tjeskobi, a poneki od njih čak i u vrlo visokom stupnju. Učenike bi trebalo upoznati s činjenicom da se uz ispitne situacije pojavljuje ispitna tjeskoba i da ju u određenoj mjeri treba gotovo uvijek i očekivati te da se uz tjeskobu redovito pojavljuju psihosomatske promjene $\mathrm{i}$ 
S. Brlas, A. Imrović, K. Jukić, I. Martinušić, T. Šokec ISPITNA TJESKOBA KOD UČENIKA UČENIČKIH DOMOVA U..

korespondirajuće misli. Važno im je pomoći da osvijeste kako određena niža razina ispitne tjeskobe može biti poticajna u ispitnoj situaciji, ali da previsoka razine tjeskobe nikako nije dobra jer ometa obrazovno postignuće i potencijalni je rizik za mentalno zdravlje. Sve navedeno važno je kako bi učenici na vrijeme naučili načine i razvili vještine suočavanja s ispitnom tjeskobom.

Učenici uzroke ispitne tjeskobe dovode u vezu sosobnom nedovoljnom pripremljenosti i/ili opsežnim gradivom, ponekad uzroke vide i u neispavanosti, ali u značajnoj mjeri i u stilovima ispitivača (profesora, nastavnika) što upućuje na potrebu dodatnog psihoeduciranja nastavnika. Također se u značajnom postotku nisu skloni za pomoć obratiti svojim nastavnicima i misle da njihovi nastavnici ili odgojitelji uopće ne prepoznaju ispitnu tjeskobu učenika, a gotovo svaki drugi ispitanik izvještava da razgovor s nastavnikom ili odgojiteljem o ispitnoj tjeskobi ne umanjuje ispitnu tjeskobu, pa bi ulaganje dodatnog napora u smjeru rada s učenicima vjerojatno rezultiralo i njihovim boljim obrazovnim postignućima čime bi se uspješnije ostvarile i glavne zadaće odgojno-obrazovnog procesa.

\section{Literatura}

Brlas, S. i Martinušić, I. (2015). Kako prevladati ispitnu tjeskobu. Virovitica: Zavod za javno zdravstvo "Sveti Rok" Virovitičko-podravske županije i Visoka škola za menadžment u turizmu i informatici u Virovitici.

Lufi D., Okasha S. i Cohen, A. (2004). Test anxiety and its effect on the personality of students with learning disabilities. Learning Disability Quarterly, 27(3), 176-184.

Raffety, B.D., Smith, R.E. i Ptacek, J.T. (1997). Facilitating and debilitating trait anxiety, situational anxiety, and coping with an anticipated stressor: a process analysis. Journal of Personality and Social Psychology, 72(4), 892-906.

Sorić, I. (2014). Samoregulacija učenja, Možemo li naučiti učiti. Zagreb: Naklada Slap.

Šimić Šašić, S. i Sorić, I. (2011). Kvaliteta interakcije nastavnik-učenik: povezanost s komponentama samoreguliranog učenja, ispitnom anksioznošću i školskim uspjehom. Suvremena psihologija 14(1), 35-55.

Živčić-Bećirević, I. (2005). Uloga automatskih misli, navika učenja i ispitne anksioznosti u objašnjenju školskog uspjeha i zadovoljstva učenika. Društvena istraživanja, 86(6), 987-1004.

\section{Examination Anxiety of Students in Dormitories in the Republic of Croatia}

Abstract: This paper analyzes the topic of mental health, more specifically the exam anxiety of pupils that stay in student dorms and its perception from the perspective of their professors-educators. Examination anxiety is common in situations when displaying knowledge, skills, or public presentation is present, especially when this is subject to others' evaluation. When low or moderate, exam anxiety can be encouraging and motivating, whereas high levels of exam anxiety may become paralyzing and prevent a successful outcome of the exam. If this situation happens on a recurring basis, it causes the inability for the pupil to achieve educational goals, which in turn becomes frustrating and stressful to them. This can have a negative impact on their mental health.

Results of this online research conducted throughout student dorms across Croatia showcase that the majority of pupils go through moderate levels of exam anxiety, and that educators perceive higher levels of anxiety that the pupils reported. Results also showcase the qualitative data about the most common physical and emotional changes pupils go through, thoughts they experience during exams, and their likelihood to look for help from educators.

Keywords: exam anxiety, mental health, educators, pupils, student dorms 


\section{Prüfungsangst bei Schülern in Kroatischen wohnheimen}

Zusammenfassung: Diese Arbeit befasst sich mit dem Problem der psychischen Gesundheit, bzw. der Prüfungsangst bei Schülern, die in Schülerwohnheimen wohnen, und ihrer Wahrnehmung durch ihre Lehrer und Erzieher. Prüfungsangst ist eine häufige Erscheinung in Situationen, in denen man seine Kenntnisse oder Fertigkeiten vor anderen zu Beweis stellen und präsentieren muss, besonders wenn die Anderen diese Leistung bewerten. Geringe oder mäßige Prüfungsangst stimuliert und motiviert die Person, sich anzustrengen, während starke Prüfungsangst lähmend wirkt und die Person oft "bremst", was zu einem Ausbleiben des Erfolgs in der Testsituation führt. Wenn sich die Situation, in der die Prüfungsangst die Durchführung der Prüfung wesentlich erschwert, wiederholt, können die Bildungsziele nicht erreicht werden, was zur Frustration und Stress führt und keine gute Prognose für die psychische Gesundheit darstellt. Die Ergebnisse dieser Online-Studie, die in Schülerwohnheimen in ganz Kroatien durchgeführt wurde, zeigen, dass die meisten Schüler eine mäßige Prüfungsangst erleben, aber auch, dass die pädagogischen Fachkrüfte bei den Schülern ein höheres Maß an Angst wahrnehmen, als diese selbst berichten. Außerdem werden die häufigsten körperlichen und emotionalen Veränderungen der Schüler, die Gedanken, die sie während der Prüfung begleiten und die Neigung, Erzieher um Hilfe zu fragen, qualitativ dargestellt.

Schlüsselwörter: Prüfungsangst, psychische Gesundheit, Pädagogen, Schüler, Schülerwohnheime 